\title{
Proses Pemanenan Paprika (Capsicum annum var. Tribeli) di Greenhouse, De Lier, Belanda Selatan, Belanda
}

\author{
Harvesting Process of Snack Paprika (Capsicum annum var. Tribeli) in Greenhouse, De Lier, Zuid- \\ Holland, Netherlands
}

\author{
Muhammad Arifianto dan Juang Gema Kartika* \\ Departemen Agronomi dan Hortikultura, Fakultas Pertanian, Institut Pertanian Bogor (BogorAgricultural \\ University), Jl. Meranti, Kampus IPB Dramaga, Bogor, 16680, Indonesia, \\ Telp. \& Faks. 0251-8629353 e-mail: agronipb@indo.net.id \\ *Penulis untuk korespondensi :
}

Disetujui 20 Agustus 2018 / Published online 3 September 2018

\begin{abstract}
The harvesting process of the sample agriculture enterprise and the production qualities of three different varieties of snack peppers in the company, is good. This could be seen from the production that reached more than $95 \%$ and not more than 4,06 \% losses. The Tribeli mini red (E20S4191) snack paprika has the highest yield and the Tribeli mini orange (E20S4216) snack paprika has the highest productivity. Based on the data comparison of the three varieties, it shows that all three of them has a good quality and can replace each other in case of scarcity in one of these varieties. The internship program at a company of the second largest snack pepper exporter country in the world helps a student increase the experience, technical skills, and managerial skills. The applied methods are direct and indirect methods. The observations which are included are the yields data, harvesting criteria, harvest weight, harvest age, number of fruits per plant, losses, and work achievements.
\end{abstract}

Keywords: harvesting, Internship activities, production quality, snack paprika

\begin{abstract}
ABSTRAK
Proses pemanenan yang dilakukan dalam perusahaan yang diteliti sudah baik. Hal ini terlihat dari produksi yang mencapai lebih dari $95 \%$ dengan kehilangan hasil panen tidak lebih dari 4,06 \%. Paprika kerucut mini dengan produksi tertinggi adalah varietas Tribeli mini merah (E20S4191). Paprika kerucut mini dengan produktivitas tertinggi adalah varietas Tribeli mini oranye (E20S4216). Berdasarkan perbandingan seluruh data ketiga varietas yang terkumpul, menunjukkan bahwa ketiga varietas tersebut memiliki kualitas yang baik dan dapat mencukupi kebutuhan masyarakat serta dapat saling menggantikan apabila terjadi kelangkaan pada salah satu varietas tersebut. Kegiatan penelitian di negara eksportir paprika kerucut mini terbesar kedua di dunia, dilaksanakan untuk meningkatkan pengalaman dan kemampuan teknis serta kemampuan manajerial dalam pengelolaan perusahaan pertanian dan mempelajari proses pemanenan serta mengamati kualitas produksi dari perbandingan tiga varietas paprika kerucut mini yang terdapat di perusahaan. Metode yang digunakan adalah metode langsung dan tidak langsung. Pengamatan yang dilakukan meliputi data hasil panen, kriteria panen, bobot panen, umur panen, jumlah buah per tanaman, kehilangan hasil, dan prestasi kerja.
\end{abstract}

Kata kunci: Kegiatan penelitian, kualitas produksi, paprika kerucut mini, pemanenan 


\section{PENDAHULUAN}

Paprika merupakan tanaman yang berasal dari Mexico, Amerika Latin dan bukan tanaman asli Indonesia (Kelley and Boyhan, 2009). Perkembangan paprika di Indonesia dari tahun 2009 sampai 2014 mengalami peningkatan dan sedikit penurunan pada tahun 2011. Data terbaru pada tahun 2014 menunjukkan peningkatan menjadi 7.031 ton (Ditjenhorti, 2015).

Paprika juga merupakan salah satu komoditas sayuran asing yang potensial untuk dikembangkan di Indonesia dan bernilai ekonomi tinggi yang merupakan famili dari Solanaceae (Savaringga, 2013). Hal tersebut ditunjukkan oleh tingginya permintaan terhadap paprika. Permintaan dari hotel berbintang rata-rata sekitar $15 \mathrm{~kg}$ paprika per hari, sedangkan swalayan membutuhkan sekitar $5 \mathrm{~kg}$ per harinya, dan tingginya permintaan tersebut belum dapat dipenuhi seluruhnya oleh petani (Prihmantoro dan Yovita, 2003). Peluang pasar luar dan dalam negeri masih terbuka lebar karena pasokan lebih kecil dibandingkan permintaannya. Rata-rata permintaan ekspor atau luar negeri adalah 100 ton per minggu, sedangkan Indonesia hanya mampu memenuhi 26 ton per minggunya. Rata-rata permintaan dalam negeri mencapai $105 \mathrm{~kg}$ per minggunya dan pasar swalayan $35 \mathrm{~kg}$ per minggu (Dasipah et al., 2011).

Kehilangan hasil panen sayuran di Indonesia mencapai $20-50 \%$. Hal ini disebabkan berkurangnya lahan pertanian, iklim yang tidak menentu di Indonesia dan penanganan panen yang kurang tepat. Penanganan panen paprika yang baik dan benar perlu dilakukan agar dapat mempertahankan kualitas buah yang dihasilkan dan mengurangi kehilangan hasil panen serta meningkatkan nilai jual (BBPP, 2015).

Paprika atau Sweet pepper yang tumbuh di Belanda dibagi menjadi beberapa jenis yaitu Bell paprika, Conicals paprika, dan mini conicals paprika (Enzazaden, 2016). Paprika yang di amati adalah jenis dari paprika kerucut mini atau mini conicals paprika/Snack pepper/Snack paprika Capsicum annuum varietas Tribeli Mini Red (E20S4191), Tribeli Mini Orange (E20S4191) dan Tribeli Mini Yellow (E20S0158). Paprika kerucut mini varietas lain yang cukup terkenal adalah Lubega (Brockhaus, 2017). Ketiga varietas Tribeli ini dikembangkan oleh perusahaan Kiepenkerl yang berada di Belanda (Schneckenprofi, 2017). Kandungan gizi yang dimiliki seperti vitamin A, K, E, dan C serta kandungan beta carotene dan lycopene menjadikan paprika banyak dikonsumsi sebagai makanan sehari-hari di negara yang memproduksinya seperti Belanda (Warsi dan Gunarti, 2013). Paprika kerucut mini juga dapat dimanfaatkan sebagai pelengkap salad, acar, atau langsung dimakan (Kang et al., 2012).

Belanda adalah negara dengan luas area yang kecil. Luas area di Belanda adalah 41.864 $\mathrm{km}^{2}$ (BBC,2016). Kondisi tersebut mengharuskan petani membuat sistem pertanian yang hemat dalam penggunaan lahan. Solusi yang dapat mengatasi sedikitnya lahan pertanian adalah penggunaan teknik budidaya hidroponik yang dapat dilakukan di rumah kaca (greenhouse). Hidroponik adalah metode pertanian tanpa menggunakan tanah sebagai media, melainkan menggunakan larutan nutrisi mineral atau bahan yang mengandung nutrisi seperti sabut kelapa, pasir, rockwool, serbuk kayu, dll. Sistem ini diharapkan dapat meningkatkan produktivitas dan kualitas sayuran tersebut (Lonardy and Mas'ud, 2009). Greenhouse sangat penting dalam mendukung produksi pertanian dikarenakan kondisi lingkungan, cahaya, kelembapan, suhu, dan irigasi yang dapat dikendalikan. Faktor lingkungan yang terkendali diharapkan dapat meningkatkan hasil panen tanaman (BBC, 2014).

Belanda adalah pengekspor paprika terbesar kedua setelah Spanyol (GAIN, 2016). Luas lahan sayuran paprika di Belanda di tahun 2013 adalah 1.300 ha. Belanda mengekspor $80 \%$ dari produksi paprika yang mencapai 462.554 ton di tahun 2012 (FAO, 2015). Artinya, hanya $20 \%$ atau sekitar 115.638 ton dari total produksi yang dikonsumsi di Belanda. Hal ini membuat Belanda menjadi tempat yang cocok untuk melakukan penelitian sayuran dalam rumah kaca dan pengamatan dari paprika. Proses pemanenan yang tepat dapat menjadi langkah awal dari upaya memperoleh kualitas hasil paprika yang optimal. Tujuan umum penelitian ini menambah pengalaman dan kemampuan teknis serta kemampuan manajerial dalam pengelolaan perusahaan pertanian. Tujuan khusus penelitian mempelajari proses pemanenan dan mengamati kualitas produksi paprika kerucut mini berdasarkan perbandingan hasil panen dan kriteria panen tiga varietas yang terdapat dalam perusahaan.

\section{METODE}

Penelitian dilaksanakan di perusahaan V.O.F. M \& W van Paassen, De Lier, Provinsi Belanda Selatan pada tanggal 3 April - 30 Juni 2017. Kegiatan penelitian dilaksanakan dengan dua metode, yaitu metode langsung dan tidak langsung. Metode langsung dilaksanakan dengan melakukan pengamatan secara langsung di lapang 
serta mengikuti kegiatan teknis budidaya berupa pemeliharaan dan pemanenan paprika. Metode tidak langsung dilaksanakan dengan memperoleh dan mempelajari data sekunder berupa arsip perusahaan, laporan dari perusahaan dan studi pustaka. Kegiatan selama penelitian hanya terdiri atas satu aspek utama, yaitu aspek teknis yang dilakukan selama tiga bulan sebagai karyawan harian lepas (KHL) dan pada bulan ketiga dilakukan kegiatan tambahan sebagai pengawas dan pendamping pekerja baru. Aspek teknis mencakup pemeliharaan tanaman, pengendalian hama dan penyakit serta pemanenan. Aspek manajerial yang dilakukan berupa pengawasan serta pendampingan terhadap karyawan-karyawan baru yang datang pada bulan ketiga dan diskusi dengan supervisor diluar jam kerja. Semua kegiatan yang telah dilakukan dicatat pada jurnal harian kegiatan penelitian.

\section{Pengamatan dan Pengumpulan Data}

Pengumpulan data dan informasi penelitian yang dikumpulkan berupa data primer dan data sekunder. Pengumpulan data primer diperoleh dengan melakukan pengamatan langsung terhadap semua kegiatan yang berkaitan dengan aspek teknis dari kegiatan-kegiatan secara langsung di lapangan dan diskusi dengan manager dan karyawan tetap. Data sekunder yang dikumpulkan diantaranya kondisi umum perusahaan meliputi lokasi kebun, luas area dan tata guna lahan, keadaan iklim dan tanah, fasilitas infrastruktur perusahaan dan hasil produksi.

Data primer yang dikumpulkan meliputi komponen panen dan pascapanen yang dilakukan dari minggu ke-14 sampai minggu ke-25 atau selama penelitian yaitu bulan April sampai Juni. Komponen peubah yang diamati adalah :

1. Kriteria Panen

a) Ukuran buah diukur berdasarkan bobot per buah dan panjangnya dengan penggaris.

b) Warna buah, terdapat tiga varietas yang berbeda yaitu tribeli mini merah, oranye dan kuning.

c) Kelunakan buah, dibagi menjadi lunak atau tidak lunak

d) Bentuk buah, lurus atau tidak lurus

e) Kemanisan buah diamati berdasarkan studi literatur pada perusahaan

2. Bobot hasil panen

a) Bobot panen per buah, diambil 5 buah yang dipanen secara acak per varietas. Pengamatan dilakukan dua kali pada bulan Mei dan Juni pada tanggal yang sama. b) Bobot hasil panen per minggu, paprika hasil panen dalam greenhouse ditimbang setiap harinya dan diakumulasikan per minggu. Perusahaan sudah memulai panen pertama pada bulan Maret atau minggu ke-11, namun pengamatan dan perhitungan aspek khusus dimulai pada bulan April sampai Juni atau minggu ke-14 sampai minggu ke25.

3. Umur panen

Umur panen hanya menggunakan data perusahaan.

4. Jumlah buah per tanaman

Bakal buah paprika dihitung dari 10 tanaman per varietas seluas $1 \mathrm{~m}^{2}$, sehingga total yang diamati 30 tanaman.

5. Kehilangan hasil

Kehilangan hasil meliputi buah lunak, buah terserang hama dan penyakit, buah berukuran dibawah $6 \mathrm{~cm}$, buah terlalu bengkok, dan susut buah. Bobot kehilangan hasil (tak layak pasar) diambil dari minggu ke-14 sampai minggu ke-25

6. Penanganan pascapanen

Kegiatan penanganan pascapanen yang dilakukan hanya berupa penyortiran dan grading yang dilakukan bersamaan dengan pemanenan.

\section{Analisis Data}

Data dan informasi yang diperoleh selama penelitian dianalisis menggunakan perhitungan matematika sederhana seperti nilai rata-rata dan persentase. Data primer dianalisis dengan uji tstudent 5\% untuk membandingkan bobot hasil panen layak dan tidak layak, bobot panen per buah dan jumlah buah per tanaman di greenhouse dengan bantuan program Star. Data sekunder dianalisis secara deskriptif.

\section{HASIL DAN PEMBAHASAN}

\section{Aspek Teknis}

Kegiatan selama penelitian hanya terdiri atas satu aspek utama, yaitu aspek teknis yang dilakukan selama tiga bulan sebagai karyawan harian lepas (KHL) dan pada bulan ketiga terdapat kegiatan tambahan sebagai pengawas dan pendamping pekerja baru. Kegiatan budidaya diawali dengan persiapan lahan dan media tanam yaitu dengan melakukan pembersihan dan 
pembongkaran seluruh isi greenhouse musim tanam sebelumnya pada awal November, lalu sterilisasi dengan menyemprot $3 \%$ Natrium hipoklorit keseluruh bagian greenhouse dan selanjutnya seluruh bagian tanah di greenhouse ditutup kembali dengan mulsa plastik putih yang baru agar tidak ditumbuhi gulma, kemudian dimasukkan rockwool guling yang baru sebagai media tanam, lalu didiamkan sampai akhir Desember karena sudah memasuki musim dingin. Persiapan setelah didiamkan adalah mengalirkan air bernutrisi ke rockwool guling tersebut dan didiamkan selama 24 jam agar rockwool guling siap ditanami bibit paprika kerucut mini. Bahan tanam berupa bibit paprika kerucut mini berumur 6 MST yang

dibeli di perusahaan lain dipindah tanamkan ke rockwool guling yang sudah dialiri larutan nutrisi tersebut.

Greenhouse memiliki tiga tangki penampungan air yang memiliki fungsi yang berbeda-beda. Tangki pertama dan kedua berfungsi menampung air yang disedot dari dalam tanah. Tangki ketiga berfungsi

menampung sisa air yang tidak diserap oleh tanaman paprika kerucut mini. Urutan proses pengairan sampai dengan pemupukan adalah air pada tangki pertama dialirkan menuju tempat sterilisasi dan disinari dengan cahaya ultraviolet untuk sterilisasi air tersebut, selanjutnya air steril dialirkan kedalam bak A, bak B, dan bak asam. Bak A adalah tempat pembuatan larutan stok A, bak B untuk pembuatan larutan stok B, dan bak asam untuk mengatur $\mathrm{pH}$ dalam air. Air yang sudah masuk kedalam bak A dan B selanjutnya akan dicampur dengan mineral-mineral nutrisi yang sudah ditentukan. Air nutrisi atau air pupuk yang sudah tercampur di masing- masing bak selanjutnya akan di campur di penampungan khusus untuk bak A, B, dan asam dan dialirkan ke seluruh tanaman melalui selang pengairan/pemupukan yang menggunakan sistem hidroponik irigasi tetes recovery drip.

Pengendalian hama dan penyakit setelah pemindahan bahan tanam adalah pemasangan enam zwavel berisi sulfur yang berfungsi sebagai fungisida alami yang bertujuan mencegah penyakit embun tepung pada daun (powdery mildew). Alat ini digantungkan di atas tanaman dengan sistem kerja gassing atau fumigasi karena akan keluar gas sulfur yang tidak terlihat yang menyebar keseluruh greenhouse. Selanjutnya akan dilepas agen biologis Montdorensis dan Orius laevigatus yang merupakan predator dari Thrips, kutu daun, dsb. Selama proses penelitian penggunaan pestisida hanya dilakukan saat beberapa jalur di dalam greenhouse terserang kutu daun dengan memasukkan 750 gram insektisida sistemik berbahan aktif $50 \%$ Pymetrozine kedalam campuran 4.500 liter air yang kemudian disatukan dengan aliran irigasi. Tanaman yang terserang akan dilepas emitter-nya selama satu hari penuh sebelum insektisida diterapkan.

Pemanenan dilakukan dari pukul 07.00 17.00 CET. Panen dilakukan dengan menggunakan gunting panen yang dicelupkan kedalam susu sebelum memulai panen agar mengurangi penyebaran bakteri atau virus

dari tiap tanaman. Hal ini sesuai dengan penelitian Barnes et al. (1999) bahwa susu memiliki pengaruh mengurangi pertumbuhan bakteri pada stainless steel. Cara melakukan panennya adalah menggunting tangkai buah sehingga terlihat sangat pendek. Hal ini bertujuan memudahkan sortasi dan packaging saat kegiatan pasca panen. Tiap pemanen mengendarai kendaraan panen yang memiliki tempat duduk dan box biru besar dengan kapasitas $12-15 \mathrm{~kg}$ untuk menampung paprika yang sesuai standar perusahaan dan box kecil berkapasitas $5 \mathrm{~kg}$ untuk menampung paprika yang dibawah standar perusahaan. Pascapanen yang dilakukan di greenhouse hanyalah sortasi saat pemanenan, penimbangan, dan pendistribusian ke lokasi pabrik grading dan pengemasan yang merupakan perusahaan lain.

\section{Kriteria panen}

Kriteria panen (Tabel 1) paprika kerucut mini di perusahaan memiliki empat hal utama yang diperhatikan yaitu: ukuran, warna, tekstur, dan bentuk. Paprika dibagi menjadi paprika (good) layak pasar dan (not good) tidak layak pasar dari empat kriteria panen tersebut.

Tabel1. Standar perusahaan untuk paprika kerucut mini yang siap dipanen

\begin{tabular}{ccc}
\hline & Good & Not Good \\
\hline Ukuran & $>6 \mathrm{~cm}$ & $<6 \mathrm{~cm}$ \\
Warna & $80 \%$ berwarna (Merah/Oranye/Kuning) & Hijau/ $>80 \%$ (Merah/Oranye/Kuning) \\
Tekstur & Tidak Lunak & Lunak \\
Bentuk & Sedikit melengkung - Lurus & melengkung, tidak lurus, bulat \\
\hline
\end{tabular}

Sumber: Arsip V.O.F. M \& W van Paassen 
Tekstur paprika kerucut mini yang termasuk kategori good adalah paprika yang berbuah padat dan tidak lunak, sedangkan paprika yang berbuah lunak atau sudah membusuk adalah paprika not good. Bentuk paprika kerucut mini yang dikategorikan good adalah paprika yang buahnya tidak melengkung atau sedikit saja melengkungnya. Kelengkungan maksimal kurang lebih 45 derajat. Apabila kelengkungan melebihi 45 derajat maka termasuk dalam kategori not good. Paprika kerucut mini yang lunak biasanya disebabkan karena buah sudah terlalu lama matang dan belum di panen atau terkena paparan suhu yang tinggi ketika terkena sinar matahari langsung sehingga mempercepat kematangannya.

Kriteria panen lainnya yang tidak dipakai oleh perusahaan adalah kemanisan buah. Paprika kerucut mini berbeda dengan varietas Capsicum annuиm lainnya yang biasanya memiliki rasa pedas. Ketiga varietas dari paprika kerucut mini ini memiliki tingkat kemanisan berdasarkan nilai brix sebesar 9 untuk warna kuning serta 10 untuk warna merah dan oranye (Enzazaden, 2016).

\section{Aspek Manajerial}

Kegiatan yang dilakukan mahasiswa penelitian selama tiga bulan adalah sebagai karyawan harian lepas yang difokuskan dengan pemanenan paprika kerucut mini. Pada bulan terakhir penulis membantu karyawan lama dalam mengawasi dan mengelola dua tenaga kerja baru ataupun tenaga kerja siswa sekolah yang datang pada hari sabtu. Tugas dari penulis adalah memeriksa apakah jalur panen karyawan tersebut terdapat paprik yang tertinggal, memastikan karyawan dan siswa sekolah memanen pada jalur yang tepat, dan membantu mereka apabila mengalami kesulitan.

Tabel 2. Perbandingan prestasi kerja mahasiswa dan karyawan

\begin{tabular}{lccc}
\hline \multirow{2}{*}{ Kegiatan } & \multicolumn{3}{c}{ Rata-rata Prestasi Kerja } \\
\cline { 2 - 4 } & Mahasiswa & Karyawan & Standar \\
\hline Pemanenan & 32,77 kg jam-1 & 33,69 kg jam-1 & $30 \mathrm{~kg} \mathrm{jam}-1$ \\
Pengambilan ajir & 9750 batang & 17250 batang & - \\
Pengambilan Plastik ring & 5 jalur jam-1 & 4,5 jalur jam-1 & - \\
\hline
\end{tabular}

Sumber: Jurnal penulis dan arsip V.O.F M \& W van Paassen

\section{Perencanaan Panen}

Perusahaan sudah memperkirakan bahwa varietas berwarna merah harus lebih banyak dikarenakan ukuran buah yang lebih kecil dibandingkan paprika varietas berwarna oranye dan kuning (Tabel 3). Perusahaan merencanakan akan memulai panen pada awal bulan Maret karena bulan tersebut sudah masuk musim semi dan buah yang dihasilkan sudah cukup banyak.

Tabel 3. Rata-rata bobot panen per buah pada bulan Mei dan Juni

\begin{tabular}{lccc}
\hline \multicolumn{1}{c}{ Warna } & $\begin{array}{c}\text { Mei (29 MST) gram per } \\
\text { buah }\end{array}$ & Juni (33 MST) gram per buah & Rata-rata (gram per buah) \\
\hline Merah & 24,06 & 28,08 & 26,07 \\
Oranye & 31,06 & 35,00 & 33,03 \\
Kuning & 28,94 & 33,34 & 31,14 \\
\hline
\end{tabular}

Sumber: Hasil pengamatan

Perhitungan perencanaan yang dilakukan perusahaan adalah menghitung jumlah bakal buah atau bunga yang sudah anthesis pada 10 tanaman contoh di tiap varietasnya. Tujuannya untuk memprediksi waktu panen antara ketiga varietas paprika yang akan dipanen terlebih dahulu dan menentukan jumlah pemanen yang dibutuhkan untuk memanen paprika tersebut. Perusahaan juga sudah memperkirakan bahwa pada bulan Mei dan Juni akan menjadi puncak panen paprika kerucut mini dan mulai menurun dan kembali seperti bulan Maret dan April pada bulan Agustus sampai November.

Perusahaan memiliki target hasil panen yang dibutuhkan berubah-ubah tiap minggunya.
Saat memasuki bulan Juni hasil panen sering sekali melebih target produksi, sehingga karyawan diminta berhenti pada pukul 12 siang setiap hari Jumat saat sedang memanen karena produksi sudah mencapai atau melebihi target. Hal ini mengakibatkan masih adanya paprika yang tersisa pada tanaman yang harus dipanen kembali pada hari Senin, sebagian dari paprika-parika tersebut ada yang menjadi terlalu lunak bahkan membusuk pada hari Senin saat karyawan akan memulai panen.

\section{Organisasi panen}

Proses pemanenan di perusahaan dilaksanakan oleh pemanen dari pukul 07.00- 
17.00 CET. Jumlah pemanen tiap bulannya berbeda tergantung dari produktivitas dan jumlah buah per tanaman hasil perhitungan pemilik perusahan. Saat penulis melakukan penelitian panen yang dilakukan bulan April terdapat 4 orang pemanen termasuk penulis. Pemanen pada bulan Mei berjumlah 5 orang termasuk penulis dan pada bulan Juni adalah 6 orang termasuk penulis.

Luas areal tanam adalah $10.800 \mathrm{~m}^{2}$ dan populasi tanaman sebanyak 26.268 tanaman (diasumsikan $10 \%$ tanaman mati). Seorang tenaga kerja dapat memanen paprika kerucut mini sebanyak $30 \mathrm{~kg} \mathrm{jam}^{-1}$ per harinya, sehingga target minimal harus di panen pemanen adalah $30 \mathrm{~kg}$ jam $^{-1}$ per harinya. Target ini terkadang berubah pada beberapa minggu menjadi minimal $35 \mathrm{~kg}$ $\mathrm{jam}^{-1}$ per harinya. Perusahaan juga memiliki target maksimum per harinya. Apabila target minimal 30 $\mathrm{kg} \mathrm{jam}^{-1}$, maka target maksimum adalah $35 \mathrm{~kg}$ $\mathrm{jam}^{-1}$, apabila target minimal $35 \mathrm{~kg} \mathrm{jam}^{-1}$, maka target maksimum adalah $39-40 \mathrm{~kg} \mathrm{jam}^{-1}$.

Waktu panen yang dibutuhkan sesuai rumus tersebut adalah 150 jam atau sekitar 6,25 hari. Pemanen paprika memiliki prestasi kerja diatas $35 \mathrm{~kg} \mathrm{jam}^{-1}$ sehingga $10.800 \mathrm{~m}^{2}$ greenhouse dapat diselesaikan kurang dari 5,35 hari atau 5 hari saja. Apabila karyawan pemanen memanen dengan melebihi target maksimum $35 \mathrm{~kg} \mathrm{jam}^{-1}$ atau $39-40 \mathrm{~kg} \mathrm{jam}^{-1}$, maka karyawan tersebut akan mendapat bonus upah senilai bekerja setengah jam, namun jika kurang dari target minimal $30 \mathrm{~kg}$ $\mathrm{jam}^{-1}$ atau $35 \mathrm{~kg} \mathrm{jam}^{-1}$ karyawan akan mendapat potongan upah senilai bekerja setengah jam.

\section{Aspek Khusus}

Hasil panen snack paprika atau paprika kerucut mini budidaya hidroponik sistem irigasi tetes yang dilakukan perusahaan V.O.F. M \& W van Paassen telah sesuai berdasarkan SOP perusahaan (Tabel 1). Pemanenan pertama kali dilakukan pada minggu ke-11 atau pada bulan Maret 2017 dan akan diakhiri pada minggu pertama bulan November 2017. Total hasil panen layak pasar minggu ke-14 sampai dengan minggu ke-25 atau bulan April sampai bulan Juni 2017 adalah $71.882 \mathrm{~kg}$ dengan rincian panen paprika kerucut mini merah adalah $27.866 \mathrm{~kg}$, oranye $23.136 \mathrm{~kg}$ dan kuning $20.880 \mathrm{~kg}$. Produktivitas tertinggi (Tabel 4) berturut- turut dari ketiga varietas tersebut sampai dengan minggu ke-25 dimiliki oleh varietas tribeli mini oranye dengan nilai 71,40 ton hektar $^{-1}$, selanjutnya varietas tribeli mini kuning 69,05 ton hektar ${ }^{-1}$ dan varietas tribeli mini merah 61,43 ton hektar ${ }^{-1}$. Hasil produktivitas yang ada bukan merupakan produktivitas satu musim tanam dikarenakan satu musim tanam paprika kerucut mini di perusahaan adalah sampai bulan November, sedangkan data yang ada hanya sampai bulan Juni atau sekitar 3,5 bulan. Hal ini dapat menunjukkan bahwa produktivitas paprika kerucut mini di perusahaan dalam satu musim atau bulan Maret sampai November atau 8,5 bulan dapat di asumsikan tiga kali lipat dari data yang ada yaitu, merah sebesar 184,29 ton hektar ${ }^{-1}$, oranye sebesar 214,20 ton hektar ${ }^{-1}$ dan kuning sebesar 207,15 ton hektar ${ }^{-1}$.

Tabel 4. Hasil panen layak dan tak layak pasar dan produktivitas ketiga varietas tribeli mini minggu ke-14 sampai minggu ke-25

\begin{tabular}{lccc}
\hline \multicolumn{1}{c}{ Warna } & Bobot layak pasar total $(\mathrm{kg})$ & $\begin{array}{c}\text { Bobot tak layak pasar total } \\
(\mathrm{kg})\end{array}$ & Produktivitas (ton per ha) \\
\hline Merah & 27.866 & 931 & 61,43 \\
Oranye & 23.136 & 928 & 71,40 \\
Kuning & 20.88 & 883 & 69,05 \\
Total & 71.882 & 2.742 & 66,56 \\
\hline
\end{tabular}

Sumber: Arsip V.O.F M \& W van Paassen

Menurut Ditjenhorti (2015), Produktivitas paprika secara menyeluruh di Indonesia pada tahun 2014 adalah 22,25 ton hektar ${ }^{-1}$. Produktivitas paprika menurut Garutkab (2009) pada kelompok tani paprika di Garut sudah dapat mencapai 100 ton hektar ${ }^{-1}$ untuk teknik budi daya menggunakan substrat di dalam greenhouse yang merupakan perlakuan yang sama seperti di Belanda. Artinya, produktivitas paprika lokal secara menyeluruh masih lebih rendah dari produktivitas paprika milik perusahaan V.O.F M \& W van Paassen di Belanda, namun produktivitas di kelompok tani Garut menggunakan sistem yang sama seperti di Belanda sudah lebih tinggi dari produktivitas perusahaan V.O.F $M$ \& $\mathrm{W}$ van Paaassen yang hanya sampai bulan Juni. Apabila diasumsikan produktivitas perusahaan V.O.F. $\mathrm{M} \& \mathrm{~W}$ van Paassen sudah mencapai bulan November, maka produktivitas paprika Indonesia dengan perlakuan yang sama baru mencapai setengah dari produktivitas paprika perusahaan.

Peningkatan jumlah panen paprika kerucut mini tiap minggunya dapat disebabkan 
oleh peralihan musim dari musim semi menuju musim panas. Menurut Sutoyo (2011), cahaya sangat berpengaruh pada saat pembungaan tanaman. Keadaan musim panas memiliki intensitas cahaya dan kelembaban udara yang lebih tinggi sehingga dapat memaksimalkan potensi fotosintesis tanaman paprika kerucut mini dan mencegah kerontokan bunga agar bunga yang mekar dapat menjadi buah.

Varietas Tribeli mini merah E20S4191 memiliki hasil panen tertinggi, namun produktivitas tertinggi dimiliki varietas tribeli mini oranye E20S4216. Hal ini disebabkan oleh jumlah tanaman varietas tribeli mini merah ini lebih banyak dibandingkan varietas tribeli mini oranye dan kuning, sehingga produksi paprika tribeli mini merah lebih besar dibandingkan kedua varietas lainnya.

Dilihat dari hasil uji $\mathrm{t}$ Tabel 5 dapat diketahui saat jumlah tanaman varietas berwarna merah lebih banyak dari oranye dan oranye lebih banyak dari kuning, maka varietas berwarna merah dengan oranye memiliki perbedaan hasil panen layak pasar yang nyata dan merah dengan kuning memiliki perbedaan hasil panen layak pasar yang sangat nyata, namun tidak memiliki perbedaan yang nyata antara varietas berwarna oranye dengan kuning. Apabila jumlah tanaman varietas di greenhouse disamakan jumlahnya, ternyata Tabel 6 menunjukkan tidak ada perbedaan yang nyata antara ketiga varietas tersebut.

Tujuan perusahaan melebihkan jumlah varietas berwarna merah karena di pasaran varietas berwarna oranye sudah lebih banyak dan varietas berwarna kuning rasanya kurang manis dari kedua varietas lainnya. Artinya, tindakan perusahaan dalam meningkatkan jumlah tanaman varietas berwarna merah menjadi 9.960 tanaman berpengaruh nyata meningkatkan hasil panen namun tidak berpengaruh nyata pada varietas oranye yang menjadi 8.216 karena hanya sedikit saja dibandingkan varietas kuning sebanyak 8.092 tanaman.

Tabel 5. Hasil uji data hasil panen layak pasar paprika kerucut mini perusahaan

\begin{tabular}{ccccc}
\hline Peubah & DF & t Hitung & $\operatorname{Pr}(>|t|)$ & Interpretasi \\
\hline M - O & 12 & 23.600 & 0,0362 & $*$ \\
M - K & 12 & 31.700 & 0,0081 & $* *$ \\
O - K & 12 & 0,2617 & 0,798 & tn \\
\hline
\end{tabular}

Keterangan: (M) Merah, (O) Oranye, (K) Kuning, $\left(^{*}\right)$ nyata, $\left({ }^{* *}\right)$ sangat nyata, dan (tn) tidak nyata

Tabel 6. Hasil uji t data hasil panen layak pasar per tanaman

\begin{tabular}{ccccc}
\hline Peubah & DF & t Hitung & $\operatorname{Pr}(>|t|)$ & Interpretasi \\
\hline M - O & 11 & -16.800 & 0,1219 & tn \\
M - K & 11 & -10.600 & 0,3115 & tn \\
O - K & 11 & 0,2757 & 0,7879 & tn \\
\hline
\end{tabular}

Keterangan: (M) Merah, (O) Oranye, (K) Kuning, $\left(^{*}\right)$ nyata, $\left({ }^{* *}\right)$ sangat nyata, dan (tn) tidak nyata

\section{Kehilangan hasil panen}

Produksi paprika kerucut mini dengan kualitas yang baik dan jumlah yang besar tentu tetap memiliki hasil panen yang berkualitas rendah bahkan tidak diterima pasar. Ukuran yang terlalu kecil, bentuk yang tidak sesuai, tekstur yang terlalu lunak, buah yang terserang penyakit, buah yang membusuk atau rusak karena pemanen, serta susutnya buah akibat menguapnya kandungan air dalam buah. Tabel 4 menunjukkan bahwa pengamatan dilakukan dari minggu ke-14 sampai minggu ke-25. Faktor-faktor tersebut termasuk kedalam kehilangan hasil panen atau hasil panen tak layak pasar yang terjadi dalam greenhouse V.O.F M \& W van Paassen. Hasil uji t Tabel 7 menunjukkan bahwa kehilangan hasil panen dari ketiga varietas paprika kerucut mini tidak menunjukkan perbedaan yang nyata.

Tabel 7. Hasil uji t data losses (bobot tak layak pasar) per tanaman

\begin{tabular}{ccccc}
\hline Peubah & DF & t Hitung & Pr $(>|t|)$ & Interpretasi \\
\hline M - O & 11 & $-1,3$ & 0,22 & tn \\
M - K & 11 & $-1,41$ & 0,1855 & tn \\
O-K & 11 & $-0,4776$ & 0,6423 & tn \\
\hline
\end{tabular}

Keterangan: (M) Merah, (O) Oranye, $(\mathrm{K})$ Kuning, $\left(^{*}\right)$ nyata, $(* *)$ sangat nyata, dan (tn) tidak nyata

Faktor kehilangan hasil panen pada varietas berwarna merah adalah banyaknya buah yang bertekstur lunak, busuk, berukuran terlalu kecil, tidak berbentuk kerucut, dan sedikit yang terserang penyakit. Faktor kehilangan hasil panen pada varietas berwarna oranye adalah banyaknya 
buah yang berbintik hitam padahal ukuran serta teksturnya sesuai standar perusahaan, sedikit yang berukuran kecil, terserang penyakit dan bertekstur lunak. Faktor kehilangan hasil panen pada varietas berwarna kuning seimbang antara yang berukuran kecil, tekstur lunak dan berbintik hitam. Buah berbintik hitam baru banyak muncul pada akhir bulan Mei dan sepanjang bulan Juni yang mengakibatkan kehilangan hasil panen paprika varietas berwarna oranye dan kuning meningkat dari sebelumnya, sedangkan paprika varietas merah semakin meningkat kehilangan hasil-nya karena buah yang berukuran dibawah $6 \mathrm{~cm}$ terus bertambah. Faktor kehilangan hasil akibat susutnya bobot buah hasil panen dapat terjadi apabila paprika hasil panen terkena sinar matahari terik dan disimpan terlalu lama sebelum packaging. Kehilangan hasil yang terjadi akibat susutnya bobot menurut pemilik perusahaan V.O.F M \& W van Paassen adalah berkurang 1\% dari bobot total per harinya.

Tabel 8. Persentase hasil panen perusahaan minggu ke-14 sampai ke-25

\begin{tabular}{lcc}
\hline \multicolumn{1}{c}{ Varietas } & \% Hasil panen layak pasar & \% Hasil panen tak layak pasar \\
\hline Merah & 96,77 & 3,23 \\
Oranye & 96,14 & 3,86 \\
Kuning & 95,94 & 4,06 \\
\hline
\end{tabular}

Keterangan: (M) Merah, (O) Oranye, $(\mathrm{K})$ Kuning, $(*)$ nyata, $(* *)$ sangat nyata, dan (tn) tidak nyata

Tabel 8 menunjukkan bahwa persentase hasil panen layak pasar dari masing-masing varietas selalu lebih dari $95 \%$ dan persentase hasil panen tak layak pasarnya dibawah 5\%. Persentasi hasil panen layak pasar tertinggi dimiliki paprika varietas tribeli mini merah, diikuti tribeli mini oranye lalu kuning. Persentase hasil panen tak layak pasar tertinggi dimiliki oleh paprika varietas tribeli mini kuning diikuti tribeli mini oranye lalu merah.

\section{Bobot panen per buah}

Snack paprika atau paprika kerucut mini pada perusahaan V.O.F $M$ \& $\mathrm{W}$ van Paassen

Tabel 9. Hasil uji bobot panen per buah memiliki bobot panen per buahnya (Tabel 3) yang beragam. Paprika kerucut mini varietas berwarna oranye dan kuning memiliki perbedaan bobot panen per buah sangat nyata (Tabel 9) yang lebih besar dibandingkan varietas berwarna merah. Paprika varietas tribeli mini merah memiliki ratarata bobot buah 26,07 gram, varietas tribeli mini oranye 33,03 gram dan varietas tribeli mini kuning 31,14 gram. Hal ini sesuai menurut Enzazaden (2016) bahwa rata-rata bobot buah varietas tribeli mini merah, oranye dan kuning berturut-turut adalah $25-30$ gram, $30-35$ gram dan $30-35$ gram.

\begin{tabular}{ccccc}
\hline Peubah & DF & t Hitung & $\operatorname{Pr}(>|t|)$ & Interpretasi \\
\hline M - O & 4 & $-7,27$ & 0,0019 & $* *$ \\
M - K & 4 & $-4,93$ & 0,0079 & $* *$ \\
O - K & 4 & 1,76 & 0,1535 & tn \\
\hline
\end{tabular}

Keterangan: (M) Merah, $(\mathrm{O})$ Oranye, $(\mathrm{K})$ Kuning, $(*)$ nyata, $(* *)$ sangat nyata, dan (tn) tidak nyata

Bobot panen varietas tribeli mini merah yang paling rendah menyebakan perusahaan meningkatkan jumlah tanaman agar dapat menyamakan atau melebihi bobot hasil panen varietas lainnya. Hasil di lapang menunjukkan bahwa bobot hasil panen yang dihasilkan paprika kerucut mini varietas tribeli mini merah secara keseluruhan lebih besar dibandingkan kedua varietas lainnya. Hal ini ditunjukkan oleh hasil uji $\mathrm{t}$ (Tabel 5) bahwa perbandingan varietas berwarna merah dengan oranye berpengaruh nyata dan merah dengan kuning berpengaruh sangat nyata dengan varietas merah memiliki nilai bobot hasil panen yang lebih besar. Artinya, tindakan yang dilakukan perusahaan sudah tepat dalam meningkatkan jumlah tanaman atau jalur dari varietas tribeli mini merah dan menurut Zahra (2012), bobot panen per buah pada paprika tidak dipengaruhi oleh kandungan nutrisi yang diberikan, melainkan karena bawaan genetik dari varietas paprika.

\section{Jumlah buah per tanaman}

Snack paprika atau paprika kerucut mini memiliki perbedaan jumlah buah per tanaman yang muncul tiap bulannya. Data jumlah buah per tanaman yang tumbuh dapat menjadi salah satu faktor dalam penentuan perencanaan panen paprika kerucut mini dalam greenhouse. Data bobot panen per buah menunjukkan bahwa paprika varietas berwarna merah memiliki bobot buah yang paling rendah dibandingkan varietas 
berwarna oranye dan kuning, sedangkan paprika varietas berwarna merah menunjukkan hasil panen atau produksi panen per minggunya yang lebih besar dibandingkan paprika varietas berwarna oranye dan kuning.

Tabel 10. Hasil uji t data perbandingan jumlah buah per tanaman antar varietas

\begin{tabular}{ccccc}
\hline Peubah & DF & t Hitung & $\operatorname{Pr}(>|t|)$ & Interpretasi \\
\hline M - O & 11 & 41,700 & 0,0016 & $* *$ \\
M - K & 11 & 0,6317 & 0,5405 & tn \\
O - K & 11 & $-2,700$ & 0,0207 & $*$ \\
\hline
\end{tabular}

Keterangan: (M) Merah, (O) Oranye, $(\mathrm{K})$ Kuning, $\left({ }^{*}\right)$ nyata, $(* *)$ sangat nyata, dan (tn) tidak nyata

Hal yang dapat memengaruhi banyaknya hasil panen paprika varietas berwarna merah selain jumlah jalur tanam yang lebih banyak adalah jumlah buah atau bunga yang berhasil menjadi bakal buah per tanaman muncul tiap bulannya. Paprika varietas berwarna merah memiliki rata-rata jumlah buah per tanaman paling tinggi dan sangat berbeda nyata (Tabel 10) dibandingkan varietas berwarna oranye, namun tidak berbeda nyata terhadap varietas berwarna kuning. Paprika varietas berwarna oranye memiliki rata-rata jumlah buah per tanaman paling rendah dibandingkan kedua varietas lainnya. Artinya, jumlah buah yang tumbuh per tanamannya dapat menjadi pengaruh besarnya hasil panen atau produksi dari varietas berwarna merah.

\section{Umur panen}

Umur panen memiliki pengaruh dalam menentukan waktu dilakukannya pemanenan pada perusahaan V.O.F. $\mathrm{M} \& \mathrm{~W}$ van Paassen. Umur panen berdasarkan literatur perusahaan pada Tabel 11 menunjukkan bahwa paprika kerucut mini berwarna merah memiliki umur panen tercepat pada musim dingin menuju semi dibanding kedua varietas lainnya dan paprika kerucut mini berwarna oranye memiliki umur panen terlambat pada musim dingin menuju semi. Hal ini terlihat pada hasil panen layak pasar minggu ke-14 yang merupakan awal musim semi menunjukkan perbedaan produksi yang cukup tinggi antara paprika varietas berwarna merah dengan oranye. Varietas berwarna merah pada minggu ke-14 menghasil $430 \mathrm{~kg}$ buah, varietas berwarna oranye menghasilkan $85 \mathrm{~kg}$ buah dan varietas berwarna kuning menghasilkan $303 \mathrm{~kg}$ buah.

Tabel 11. Rata-rata umur panen setelah anthesis berdasarkan musim

\begin{tabular}{cccc}
\hline & Merah (hari) & Orange (hari) & Kuning (hari) \\
\hline Dingin-Semi & 40 & 45 & 42 \\
Semi-Panas & 30 & 30 & 30 \\
\hline
\end{tabular}

Sumber: Arsip V.O.F M \& W van Paassen

\section{KESIMPULAN}

Berdasarkan kegiatan yang terlaksana dapat disimpulkan bahwa kegiatan penelitian di V.O.F $M$ \& $\mathrm{W}$ van Paassen mampu meningkatkan kemampuan teknis dan manajemen penulis dalam kegiatan budidaya tanaman hidroponik irigasi tetes khususnya paprika kerucut mini, sehingga dapat menjadi ilmu tambahan untuk dunia kerja. Proses pemanenan yang dilakukan oleh perusahaan dapat dikatakan sangat baik karena sudah dapat memenuhi permintaan pasar dengan persentase layak pasar dapat mencapai lebih dari $95 \%$ dengan kehilangan hasil panen yang tidak lebih dari $4,06 \%$. Paprika dengan produksi tertinggi dimiliki oleh varietas tribeli mini merah (E20S4191) dikarenakan jumlah tanaman yang lebih banyak, jumlah buah per tanaman yang lebih banyak dan umur panen yang yang lebih cepat pada musim dingin menuju semi, namun memiliki ukuran buah yang paling kecil. Produktivitas tertinggi dimiliki paprika varietas tribeli mini oranye (E20S4216) dan memiliki ukuran buah terbesar.

Perbandingan ketiga varietas berdasarkan seluruh data yang terkumpul dari hasil panen, kriteria panen, bobot panen, kehilangan hasil panen dan jumlah buah per tanaman menunjukkan adanya perbedaan-perbedaan antara masingmasing varietas. Beberapa varietas ada yang menunjukkan perbedaan yang sangat nyata, nyata, maupun tidak nyata. Terdapat pula data yang menunjukkan tidak adanya perbedaan yang nyata terhadap ketiga varietas tersebut sehingga dapat dikatakan bahwa ketiga varietas memiliki kualitas yang sama baik dan dapat mencukupi kebutuhan masyarakat serta dapat saling menggantikan apabila terjadi kelangkaan pada salah satu varietas tersebut. 


\section{DAFTAR PUSTAKA}

[BBC] British Broadcasting Corporation. 2014. Netherlands country. [Internet] [diunduh 2017 Februari 17] tersedia pada [www.bbc.co.uk]

2016. Economics of greenhouse. [Internet] [diunduh 2017 September 7] tersedia pada [www.bbc.co.uk].

[BBPP] Balai Besar Pelatihan Pertanian. 2015. Pasca Panen Sayuran. BBPP, Lembang

Barnes, L.M, M. R. Adams, A. H. L. Chamberlain 1999. Effect of milk proteins on adhesion of bacteria to stainless steel surfaces. Applied and Environmental Microbiology Journal. 65(10): 4543-4548

Brockhaus, H. 2017. Paprika mini sweet conical-mini snack-geschmackssorten. . [Internet] [diunduh 2017 Agustus 21] tersedia pada [http://www.hartmann brockhaus.de]

Dasipah E., Lutfiadi R., dan Alhusaeniah E. 2011. Analisis usahatani cabai paprika (Capsicum annum var grossum) hidroponik di kecamatan cikajang kabupaten garut. Jurnal Agribisnis. 1(6): $1-14$

[Ditjenhorti] Direktorat Jendral Hortikultura. 2015. Statistik produksi hortikultura. Direktorat Jendral Hortikultura. Kementrian Pertanian Indonesia, Jakarta. Enzazaden. 2016. Paprika. . [Internet] [diunduh 2017 Juni 27] tersedia pada [https://www.enzazaden.nl]

[FAO] Food and Agriculture Organization. 2015. Production indices. FAO, United States of America

[GAIN] Global Agriculture Infornation Network. 2015. The Netherlands horticulture market. . [Internet] [diunduh 2017 Februari 16] tersedia pada [gain.fas.usda.gov]

Garutkab. 2009. Profil tanaman paprika di kabupaten Garut. Dinas Tanaman
Pangan dan Hortikultura Kabupaten Garut, Garut

Kang, W.H., B.P. Luitel, P.B. Adhikari, S. L. Shrestha. 2012. Morphologicalcharacterization of anther derived plants in minipaprika (Capsicum annuит L.). Korean Journal of Breeding Science. 44(4): 450461.

Kelley, W.T., G. Boyhan. 2009. Commercial pepper production handbook. The University of Gergia, Cooperative Extension. [Internet] [diunduh 2017 Agustus 25] tersedia pada [http://pubs.caes.uga.edu/caespubs/pubs/P DF/B1309.pdf].

Lonardy, H. Mas'ud. 2009. Sistem hidroponik dengan nutria dan media tanam yang berbeda. Jurnal Trunojoyo. 2(2):131-136

Prihmantoro, H., H. I. Yovita. 2003. Paprika Hidroponik dan Non Hidroponik. Cetakan ke-5. Penebar Swadaya, Jakarta.

Savaringga, R. 2013. Strategi pengembangan usaha cabai paprika hidroponik di koperasi petani mitra Sukamaju kecamatan Cisarua kabupaten Bandung Barat. Skripsi. IPB, Bogor

Schneckenprofi. 2017. Paprika tribeli mini. . [Internet] [diunduh 2017 Agustus 25] tersedia pada [https://www.schneckenprofi.de/paprikatribelli- mini.html?mv_arg=cc\%]

Sutoyo. 2011. Fotoperiode dan pembungaan tanaman. Jurnal Buana Sains. 11(2): $137-$ 144

Warsi, A. Guntarti. 2013. Aktivitas antioksidan pada ekstrak methanol dari paprika (Capsicum annuum L). Jurnal Ilmiah Kefarmasian. 3(1):9-19

Zahra, T.R.A. 2012. Vegetative, flowering and yield of sweet pepper as influenced by agricultural practices. Middle-East Journal of Scientific Research. 11(9):1220 $-1225$ 